JURNAL STUDI INOVASI

e-ISSN: 2775-0922

Jurnal Studi Inovasi

Vol. 2 No. 1 (2022): 33-39

https://jurnal.studiinovasi.id/jsi

DOI:

https://doi.org/10.52000/jsi.v2i1.75

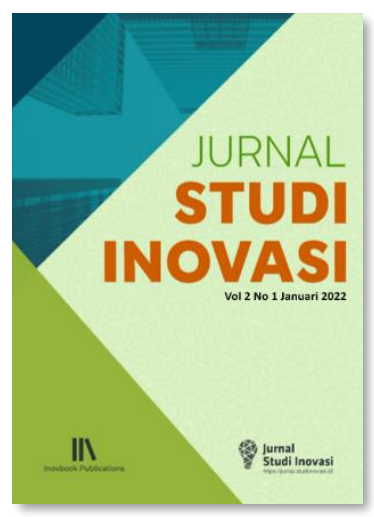

Korespondensi

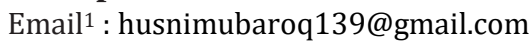
Email2 $^{2}$ : revanggit@gmail.com

\section{OPTIMALISASI GOOD GOVERNANCE DENGAN PrograM "Si Jinggo" DALAM SISTEM PEMERINTAHAN DAERAH di Kota Probolinggo}

\author{
Husni Mubaroq ${ }^{\text {* }}$, Revanggi Ayu Tantri ${ }^{*}$ \\ 1,2 Universitas Panca Marga Probolinggo | Jl. Raya Dringu, Krajan, \\ Pabean, Kec. Mayangan, Kota Probolinggo, Jawa Timur 67216
}

Disetujui: 20 Januari 2022

\begin{abstract}
Every time people always demands quality public services from bureaucratic administrators, even though the provision of services is still not satisfying the community because often the services provided tend to be complicated or convoluted, take a long time, and the large number offees charged so that the services provided seem impressed. inefficient and effective in service delivery. Related to the problems mentioned above, public services are an option for the strategic sector in order to realize good governance. Good Governance is all efforts in realizing a good government. Therefore, the Progobolinggo City Government made an innovation in the form of the Si Jinggo application (Good Governance Information Network Information System). Si Jinggo is an innovation in the form of a website-based program application that can be used to generate reports and data periodically from sub-districts or sub-districts throughout Probolinggo City which can be monitored online. From the Si Jinggo program, it is hoped that various problems such as those in subdistricts and urban villages are less aware that the data they provide is important for the regional development planning process, the lack of community data needed by Technical OPD such as population demographics and other community data, access to village data which is found on the website of the Ministry of Home Affairs is difficult to obtain and use by local governments, and the frequent occurrence of repeated requests for data in sub-districts and subdistricts can be resolved. With the Si Jinggo program, the Probolinggo City Government hopes to realize good governance optimally.
\end{abstract}

Keywords: Good Governance, Si Jinggo, Optimal, Service, Program
Karya ini dilisensikan di bawah Lisensi Internasional Creative Commons Atribusi Nonkomersial sharelike 4.0.

\begin{abstract}
Abstrak
Setiap waktu masyarakat selalu memberikan tuntutan terhadap pelayanan publik yang berkualitas dari penyelenggara birokrasi, meskipun pemberian pelayanan masih belum memuaskan masyarakat dikarenakan seringkali pelayanan yang diberikan cenderung rumit atau berbelit-belit, membutuhkan waktu yang cukup lama, dan banyaknya biaya pungutan sehingga mengakibatkan pelayanan yang diberikan terkesan tidak efisian dan efektif dalam pemberian pelayanan. Terkait dengan masalah yang telah disebutkan tadi pelayanan publik merupakan pilihan untuk sektor strategis guna mewujudkan good governance. Good Governance merupakan segala upaya dalam mewujudkan suatu pemerintahan yang baik. Oleh sebab itu Pemerintah Kota Progobolinggo membuat inovasi berupa aplikasi Si Jinggo (Sistem Informasi Jaringan Informasi Good Governance). Si Jinggo adalah inovasi berbentuk aplikasi program yang berbasis website yang dapat digunakan untuk menghasilkan laporan dan data secara berkala dari kelurahan atau kecamatan se Kota Probolinggo yang dapat dipantau secara online. Dari program Si Jinggo diharapkan
\end{abstract}


bebagai permasalahan seperti yang terdapat di kecamatan maupun kelurahan yang kurang menyadari bahwa data yang mereka berikan adalah penting bagi proses perencanaan pembangunan daerah, minimnya keberadaan data kemasyarakatan yang dibutuhkan oleh OPD Teknis seperti demografi penduduk dan data kemasyarakatan lainnya, akses data kelurahan yang terdapat pada website Kementrian Dalam Negeri sulit untuk didapatkan dan dimanfaatkan oleh Pemerintah Daerah, serta seringnya terjadi permintaan data yang berulang pada Kecamatan dan Kelurahan dapat teratasi. Dengan adanya program Si Jinggo Pemerintah Kota Probolinggo berharap dapat mewujudkan good governance secara optimal.

Kata Kunci: Good Governance, Si Jinggo, Optimal, Pelayanan, Program.

\section{Pendahuluan}

Masalah pemerintahan di berbagai daerah di Indonesia merupakan kenyataan yang tidak bisa dihindarkan pada kehidupan setiap warga negara, baik secara individu maupun bermasyarakat. Pemerintah merupakan harapan serta peluang dalam mewujudkan kesejahteraan dan kedaulatan lewat pengelolaan kebebasan yang dimiliki oleh masyarakatnya. Disisi lain pemerintah ialah tantangan serta hambatan bagi warga negara terutama saat pemerintah jauh dari pengalaman etika pemerintah. Rakyat tanpa pemerintah merupakan suatu kekacauan massal. Dalam kehidupan bermasyarakat perlu banyak peraturan, serta perlu lebih banyak dalam upaya serta kekuatan untuk menjamin peraturan-peraturan tersebut di taati.

Setiap waktu masyarakat selalu memberikan tuntutan terhadap pelayanan publik yang bermutu dari penyelenggara birokrasi, meskipun pemberian pelayanan masih belum dikatakan memuaskan masyarakat dikarenakan seringkali cenderung berbelit-belit, membutuhkan waktu lama, dan biaya pungutan banyak sehingga pelayanan yang diberikan dapat mengakibatkan terkesan tidak efisien dan efektif. Sehubungan dengan permasalahan-permasalahan tersebut pelayanan publik merupakan pilihan yang dipilih menjadi sektor strategis guna mewujudkan good governance. Pemerintah merupakan penyelenggara yang utama dalam pelayanan publik seharusnya dapat menerapkan prinsip-prinsip good governance dalam melakukan pelayanan terhadap kebutuhan masyarakat. Guna mewujudkan tujuan tersebut, diperlukan sistem pemerintahan yang baik serta efektif sehingga sesuai dengan prinsip-prinsip pelayanan publik yang bersifat demokratis.

Masyarakat berharap agar pemerintah dapat mewujudkan pelayanan publik good governance yang efektif, efisien, transparan, akuntabel, serta bertanggung jawab. Efektif memiliki arti pelayanan publik terselenggara secara tepat sasaran. Efisien dimaksudkan agar pelayanan publik dilaksanakan secara hemat berdaya guna juga berhasil guna. Transparan memiliki arti agar semua kebijakan yang dilakukan oleh penyelenggara negara dilaksanakan secara terbuka, sehingga kebijakan tersebut bisa diawasi oleh masyarakat secara langsung dan masyarakat dapat memberikan penilaian kinerja yang dilakukan pemerintah. Akuntabel dimaksudkan agar pemerintah dapat mempertanggungjawabkan segala kebijakan yang sudah ditetapkan, serta dapat mempertanggungjawabkan kinerjanya terhadap seluruh masyarakat setiap tahun penyelenggaraan pemerintahan.

Sudah terlalu banyak permasalahan terjadi di Indonesia. Beberapa pernyataan banyak yang menyatakan jikalau Indonesia telah terpuruk terutama dari segi hukumnya. Menurut Undang-Undang Dasar Negara Republik Indonesia (UUD NRI 1945) Pasal 1 ayat (3), yang menyatakan bahwa "Negara Indonesia adalah negara hukum". Oleh karena itu mengapa suatu negara yang mengklaim dirinya sebagai negara hukum bisa mengalami adanya keterpurukan hukum khususnya pada penegakan hukumnya. Pengoptimalan suatu pemerintahan yang baik atau yang bisa disebut good governance pada saat ini masih menjadi sebuah mimpi dan hanya sebatas jargon belaka. Indonesia diharuskan merubah sistem birokrasi disegala bidang agar dapat mewadahi semua kalangan masyarakat. Demi terwujudnya pengoptimalan good governance di Indonesia maka dari itu pemerintah Indonesia dalam menjalankan pemerintahannya harus secara bersih seperti yang sudah diwujudkan dalam UndangUndang Republik Indonesia Nomor 28 tahun 
1999 yang berisi tentang Penyelenggaraan Negara yang Bersih dan Bebas dari KKN yang merupakan kepanjangan dari Korupsi, Kolusi, dan Nepotisme.

Provinsi Jawa Timur di tahun 2018, menerapkan good governance melalui penilaian terhadap LPPD (Laporan Penyelenggaraan Pemerintah Daerah). Penilaian ini diatur dalam Undang-Undang Nomor 23 Tahun 2014 yang berisi tentang Pemerintahan Daerah yang salah satu aspek penilaiannya pemerintah provinsi, kabupaten dan kota berupaya dalam peningkatan kesejahteraan masyarakat lewat pemberdayaan masyarakat. Melalui UU tersebut, masyarakat diajak berkomunikasi atau disebut partisipatoris. Masyarakat juga dilibatkan untuk mengambil keputusan dalam menentukan pelayanan publik yang baik. (Website : $\quad$ http://jatimprov.go.id). Berdasarkan hal tersebut, tentunya masyarakat juga berharap hal ini tetap dilaksanakan secara konsisten mengingat good governance sangat penting untuk sitem pemerintahan yang baik.

Hal itu juga diharapkan dapat diterapkan pada kabupaten dan kota di Jawa Timur khususnya di Kota Probolinggo. Pada Kota Probolinggo terdapat kebijakan tentang pelayanan publik yaitu Kebijakan Pemerintah Kota Probolinggo dimulai tahun 2006 sebagai tahun meningkatnya pelayanan publik. Sedangkan di tahun 2010 diwajibkannya instansi dalam penyusunan Standar Pelayanan Publik (SPP). Pada tahun 2017, Kota Probolinggo melalui inovasinya memiliki sebuah aplikasi program dalam menerapkan good governance yang bernama Si Jinggo (Sistem Informasi Jaringan Informasi Good Governance). Dengan adanya $\mathrm{Si}$ Jinggo diharapkan sistem Pemerintahan Kota Probolinggo dapat berjalan dengan optimal. Berdasarkan paparan diatas, tujuan dari penelitian ini diantaranya yaitu memaparkan bagaimana pelaksanaan good governance melalui program Si Jinggo di Kota Probolinggo serta menejelaskan bagaimana kesesuaian program Si Jinggo dengan good governance.

\section{A. Good Governance}

Good governance ialah kegiatan dari lembaga pemerintah dimana dijalankan berdasarkan apa yang menjadi kepentingan rakyat dan norma berlaku dengan tujuan mewujudkan cita-cita suatu negara (Sadjijono, 2007). (IAN \& BPKP, 2005) menyatakan good governance merupakan cara pemerintah dalam berinteraksi terhadap masyarakat serta melakukan pengelolaan sumber-sumber daya pembangunan. Menurut Peraturan Pemerintah Nomor 101 Tahun 2000, bahwa good governance adalah tata kelola suatu pemerintahan dalam pengembangan serta penerapan prinsip-prinsip diantaranya prinsip transparansi, profesionalitas, pelayanan prima, akuntabilitas, efisiensi, efektifitas, demokrasi, supremasi hukum yang dapat diterima bagi semua masyarakat. Berdasarkan penjelasan yang sudah dijabarkan, dapat diambil kesimpulan bahwasanya good governance ialah suatu aktivitas pemerintah yang berjalan menurut kepentingan rakyat dan norma berlaku guna mewujudkan impian negara yang kekuasaannya diatur dari setiap tingkatan pada pemerintahan negara yang mana berkaitan dengan sumber-sumber politik, sosial-budaya, dan ekonomi.

Konsep dari good governance sudah lama dijalankan oleh semua pihak diantaranya pemerintah, pihak swasta, dan masyarakat. Tetapi dalam penyelenggaraannya masih terdapat banyak yang kurang memahami bagaimana konsep dari good governance. Banyak pihak yang mengartikan good governance ialah sebagai tata pemerintahan. Tata pemerintahan yang dimaksud bukan hanya pada definisi struktur serta manajemen lembaga yang disebut sebagai eksekutif, dikarenakan pemerintah (government) hanya merupakan salah satu dari ketiga pihak yang membentuk suatu lembaga yaitu governance. Dua pihak lain ialah sektor swasta (private sector) dan masyarakat madani (civil society). Oleh karena itu, dalam pemahaman governance sendiri diperlukan pemahaman bagaimana integrasi peran antara pemerintah (birokrasi), sektor swasta dan masyarakat dalam aturan main dengan kesepakatan secara bersama (Maryam, 2016).

\section{B. Prinsip Pemerintahan yang Baik}

Institusi pemerintah sendiri berfungsi dalam menciptakan suatu lingkungan politik dan lingkungan hukum yang kondusif, sedangkan pada sektor swasta berfungsi dalam menciptakan pekerjaan (lapangan kerja) dan pendapatan itu sendiri. Pihak yang ketiga yaitu masyarakat yang berperan dalam 
pembangunan terhadap interaksi sosial, politik dan ekonomi termasuk dalam mengajak kelompok-kelompok masyarakat agar berpartisipasi dalam aktivitas sosial, politik dan ekonomi (Sumarto, 2004).

Prinsip-prinsip pemerintahan yang baik menurut Peraturan Pemerintah Nomor 101 Tahun 2000, yang terdiri dari:

a) Profesionalitas, artinya menambah kemampuan serta moral penyelenggara suatu pemerintahan supaya bisa memberi pelayanan yang mudah, tepat, cepat dan dengan biaya yang murah

b) Akuntabilitas, artinya menambah akuntabilitas terhadap setiap pengambil keputusan di berbagai bidang yang menyangkut bagi kepentingan semua warga negara

c) Transparansi, artinya membangun kepercayaan diantara pihak pemerintah dan pihak masyarakat dengan menyediakan informasi serta memberi suatu kemudahan dalam hal memperoleh informasi yang memadai dan akurat

d) Pelayanan prima, artinya menyelenggarakan pelayanan publik secara baik meliputi mekanisme pelayanan, kejelasan biaya yang dikeluarkan, kepastian waktu, sarana dan prasarana yang lengkap, kemudahan akses dan pelayanan yang disiplin dan ramah

e) Demokrasi dan partisipasi, artinya mengajak masyarakat agar menggunakan hak berpendapat dalam pengambilan keputusan, menyangkut pada kepentingan masyarakat secara langsung maupun secara tidak langsung

f) Efisiensi dan efektivitas, artinya menjamin masyarakat terhadap pelayanan yang diberikan melalui sumber daya yang ada secara optimal serta bertanggung jawab

g) Supremasi hukum serta bisa diterima bagi seluruh masyarakat, artinya menciptakan penegak hukum yang adil untuk semua lapisan masyarakat tanpa adanya pengecualian, junjungan tinggi terhadap HAM serta memperhatikan nilainilai atau norma bermasyarakat.

Good governance memiliki ciri-ciri menurut (Kurniawan, 2006) seperti:

a. Akuntabel, ialah pembuatan serta pelaksanaan kebijakan wajib dipertanggung jawabkan b. Transparan, ialah wajib menyediakan informasi yang memadai terhadap masyarakat dalam proses pembuatan serta pelaksanaan kebijakan

c. Responsif, adalah dalam melaksanakan proses pembuatan serta pelaksanaan suatu kebijakan harus mampu untuk melayani semua stakeholder

d. Setara dan inklusif, adalah semula lapisan masyarakat wajib memperoleh kesempatan dalam hal proses pembuatan serta pelaksanaan suatu kebijakan

e. Efektif dan efisien, ialah kebijakan yang dibuat serta dilaksanakan berdasarkan sumber daya yang ada dengan baik

f. Mengikuti aturan hukum, adalah dalam proses membuat dan melaksanakan kebijakan dibutuhkan aturan yang adil dan bertanggung jawab

g. Partisipatif, adalah pembuatan serta pengaplikasian kebijakan wajib dalam membuka ruang oleh keterlibatan banyak pihak

h. Berorientasi pada konsensus (kesepakatan), ialah pembuatan dan pengaplikasian kebijakan wajib menyangkut dari hasil kesepakatan dan keputusan bersama diantara para pihak yang terlibat

Dalam memacu adanya peningkatan suatu pelayanan publik, KemenPAN RB melakukan penerapan kebijakan dari tahun 2014 yaitu diadakannya inovasi pelayanan publik bagi setiap pemerintah pusat dan daerah. Seluruh instansi pemerintah pusat dan daerah dengan adanya penerapan inovasi pelayanan publik diharapkan dapat menciptakan ide-ide kreatif atau jawaban terhadap metode atau cara kerja pada pelayanan publik. KemenPAN RB mengumpulkan setiap inovasi yang telah dibuat dan menilai pada sejumlah instansi di seluruh wilayah Indonesia. Dengan adanya kebijaka ini diharapkan kualitas serta inovasi pelayanan publik mampu untuk selalu mengalami peningkatan, sehingga dapat terus bersaing dengan instansi lain secara sehat.

\section{Metode Penelitian}

Penelitian ini memakai jenis penelitian metode kualitatif melalui pendekatan deskriptif yang bertujuan dalam mendeskripsikan, memaparkan dan menjawab secara lebih rinci permasalahan pada 
penelitian. Sumber data pada penelitian ini yaitu menggunakan sumber data sekunder. Penulis memfokuskan pada rumusan masalah yang ada. Instrumen penelitian pada penelitian ini yang digunakan oleh penulis diantaranya yaitu observasi, catatan lapangan serta studi pustaka. Analisis data dilakukan menggunakan cara pengumpulan data, menjabarkan, menganalisis serta menyajikan sesuai duduk perkara yang ada.

\section{Hasil Dan Pembahasan}

\section{A. Pelaksanaan Good Governance di Indonesia}

Pelaksanaan good governance di Negara Indonesia sendiri dilatarbelakangi oleh 2 hal yang mendasar diantaranya yaitu:

a) Tuntutan eksternal. Adanya pengaruh pada era globalisasi yang membuat kita untuk menerapkan prinsip good governance. Istilah dari good governance sendiri sudah mulai dikemukakan di Indonesia sekitar tahun 1990-an akhir, dengan seiring adanya suatu interaksi antara Pemerintahan Indonesia dengan negara-negara luar perihal kondisi objektif perihal situasi perkembangan ekonomi maupun politik dalam negeri Indonesia.

b) Tuntutan internal. Masyarakat Indonesia melihat serta merasakan bahwa banyak terjadi yang biasa disebut dengan KKN (Korupsi, Kolusi, dan Nepotisme) yang sudah sangat mewabah bagi segala aspek kehidupan. Masyarakat Indonesia menilai bahwa praktik KKN paling terlihat kuantitas dan kualitasnya yaitu dari pemerintahan seperti lembaga eksekutif, legislatif dan yudikatif.

Pelaksanaan good governance dengan baik yaitu berpegang pada 3 pilar yang pada penerapannya akan berjalan secara baik apabila didukung dengan adanya 3 pilar yang saling berhubungan tersebut diantaranya yaitu negara atau pemerintah dan perangkatperangkatnya sebagai regulator, pihak swasta atau dunia usaha sebagai pelaku pasar dan pilar ketiga yaitu masyarakat sendiri sebagai pengguna produk-produk dari dunia usaha, sehingga dalam menjalankan good governance seyogyanya dilakukan secara bersama-sama terhadap 3 pilar tersebut. Bila pelaksanaannya hanya dibebankan kepada pihak pemerintah maka keberhasilan dalam penerapan good governance belum terlaksana secara optimal dan bahkan dapat diperlukan waktu panjang untuk dikatakan berhasil.

Dalam mewujdkan good govenance Pemerintah Kota Probolingo membuat inovasi berupa aplikasi yang disebut Si Jinggo. Si Jinggo merupakan singkatan dari Aplikasi Sistem Jaringan Informasi Good Government yang merupakan serangkaian perangkat dan prosedur elektronik yang berfungsi untuk membantu mempersiapkan, mengumpulkan, mengolah, menganalisis, menyimpan, menampilkan, mengumumkan, mengirimkan, dan menyebarkan data kewilayahan secara sistematis dan dapat diakses secara online oleh pengguna aplikasi. Dengan penyelenggarakannya aplikasi $\mathrm{Si}$ Jinggo diharapkan agar segala permasalahan mengenai pengadministrasian dapat teratasi.

\section{B. Program Si Jinggo}

Si Jinggo adalah inovasi berbentuk aplikasi program yang berbasis website yang dapat digunakan untuk menghasilkan laporan dan data secara berkala dari kelurahan atau kecamatan se Kota Probolinggo yang dapat dipantau secara online. Si Jinggo ini sendiri aplikasi yang dibuat untuk optimalisasi data kemasyarakatan yang dibutuhkan oleh OPD teknis seperti demografi penduduk dan data kemasyarakatan lainnya. Si Jinggo juga dapat digunakan untuk akses data kelurahan yang dapat dijelajahi melalui website kota dengan mudah dan efisien. Hal ini dapat meminimalisir permintaan data yang berulang pada kecamatan dan kelurahan karena data yang dikirimkan sudah online berbasis website. Aparatur kelurahan dan kecamatan juga dapat secara mudah mengakses kebutuhan data dalam pengembangan kelurahan dan kecamatan. Pengguna Aplikasi Si Jinggo ini sendiri ada dua yaitu Admin Bagian Pemerintahan yang mengontrol pengisian data aplikasi dan operator masing masing kelurahan dan kecamatan.

\section{Program $\mathrm{Si}$ Jinggo Dalam Pengoptimalisasian Good Governance di Kota Probolinggo}

Si Jinggo adalah inovasi informasi data kelurahan dan kecamatan berupa aplikasi berbasis website sehingga dapat mempermudah kelurahan dan kecamatan dalam mengakses informasi data. Tujuan dan manfaat yang didapat dari dibentuk aplikasi 
Si Jinggo adalah sebagai berikut:

a. Aparatur kecamatan maupun kelurahan sudah menyadari bahwa data yang mereka berikan adalah penting bagi proses perencanaan pembangunan daerah

b. Optimalisasi data kemasyarakatan yang dibutuhkan oleh OPD Teknis seperti demografi penduduk dan data kemasyarakatan lainnya

c. Mengakses data kelurahan dan kecamatan dengan mudah dan efisien

d. Minimalisasi permintaan data yang berulang pada kecamatan dan kelurahan karena data yang dikirimkan sudah online berbasis website

Sistem aplikasi Si Jinggo juga memiliki fungsi, seperti:

a. Antar muka input data pelaporan kewilayahan tingkat kelurahan

b. Merekap dan menganalisa data agregat kewilayahan berdasarkan informasi yang telah dimasukkan pada aplikasi

c. Mencetak laporan data kewilayahan sesuai peraturan perundangan

Dalam pemanfaatan aplikasi Si Jinggo, diberikan Hak Akses Pengguna kepada pengguna aplikasi sesuai dengan kebutuhan. Pemberian Hak Akses Pengguna sebagaimana dimaksud sebagai berikut:

1. Hak akses Kecamatan

2. Hak akses Kelurahan

3. Hak akses OPD Teknis lainnya

Pemberian Hak Akses Pengguna dilakukan dengan ketentuan:

1. Setiap Kecamatan, Kelurahan, dan OPD Teknis dapat 1 hak pada akses pengguna / user access

2. Pemegang user access Kecamatan yaitu pejabat dan/atau staf yang ditunjuk oleh Camat untuk menangani pemanfaatan aplikasi Si Jinggo di Kecamatan

3. Pemegang user access Kelurahan yaitu pejabat dan/atau staf yang ditunjuk oleh Lurah untuk menangani pemanfaatan aplikasi Si Jinggo di Kelurahan

4. Pemegang user access OPD yaitu pejabat dan/atau staf yang ditunjuk oleh Kepala OPD untuk menangani pemanfaatan aplikasi Si Jinggo di Kecamatan
Kewajiban bagi pemegang hak akses pengguna diantaranya yaitu mengkoordinasikan dalam mengelola aplikasi $\mathrm{Si}$ Jinggo pada ruang lingkup OPD, mengkoordinasikan dalam pemenuhan data yang digunakan untuk bahan pelaporan $\mathrm{Si}$ Jinggo beserta dokumen pendukung lainnya pada setiap stakeholder yang terkait, memverifikasi data serta dokumen pendukung lainnya sebelum dilakukan entry data pada aplikasi dan mengikuti ketentuan dan mekanisme yang ada pada aplikasi. Pemegang user access di OPD dengan penunjukan oleh Kepala OPD lewat Surat Perintah Kepala OPD dan disampaikan langsung kepada Kepala Bagian Pemerintahan Sekretariat Daerah Kota Probolinggo pada awal bulan Januari tahun berjalan.

Program Si Jinggo memiliki banyak manfaat dan tujuan guna mewujudkan good governance. Melalui aplikasi $\mathrm{Si}$ Jinggo Pemerintah Kota Probolinggo berupaya mewujudkan good governance secara optimal serta berbagai permasalahan dapat teratasi.

\section{KESIMPULAN DAN SARAN}

Karena adanya berbagai permasalahan di paratur kecamatan maupun kelurahan seperti kurang menyadari bahwa data yang mereka berikan adalah penting bagi proses perencanaan pembangunan daerah, minimnya keberadaan data kemasyarakatan yang dibutuhkan oleh OPD Teknis seperti demografi penduduk dan data kemasyarakatan lainnya, akses data kelurahan yang terdapat pada website Kementrian Dalam Negeri sulit untuk didapatkan dan dimanfaatkan oleh Pemerintah Daerah serta seringnya terjadi permintaan data yang berulang pada Kecamatan dan Kelurahan sehingga Pemerintah Kota Probolinggo membuat inovasi baru untuk meuwujudkan good governance berupa aplikasi Si Jinggo. Si jinggo kepanjangan dari Sistem Informasi Jaringan Informasi Good Governance. Si Jinggo adalah inovasi berbentuk aplikasi program yang berbasis website yang dapat digunakan untuk menghasilkan laporan dan data secara berkala dari kelurahan atau kecamatan se Kota Probolinggo yang dapat dipantau secara online.

Dengan adanya aplikasi $\mathrm{Si}$ Jinggo diharapkan agar pemerintah kota Probolinggo dapat mengoptimalkan laporan dan 
administrasi yang terdapat di kelurahan serta kecamatan. Serta dapat mendorong kinerja aparatur kelurahan juga penguatan kelembagaan masyarakat. Masyarakat juga diharapkan untuk ikut serta dalam proses pembangunan kelurahan melalui program $\mathrm{Si}$ Jinggo.

\section{UCAPAN TERIMA KASIH}

Ucapan terima kasih diberikan kepada berbagai pihak terkait yang sudah membantu penulis menyelesaikan tulisan ini. Ucapan terima kasih juga diberikan kepada orang tua, teman-teman, saudara penulis yang telah mendukung penulis secara sabar agar dapat menyelesaikan tulisan ini. Terima kasih kepada Universitas Panca Marga Probolinggo serta para dosen yang telah membimbing saya dan yang telah memberi saya wadah serta kepercayaan untuk melakukan penelitian. Semoga tulisan ini dapat bermanfaat untuk kita semua.

\section{Daftar Pustaka}

IAN \& BPKP. 2000. Pelayanan Publik. Malang: CV Citra Malang.

Kasmir. 2006. Manajemen Perbankan. Jakarta: PT. Raja Grafindo Persada.

Kurniawan, Teguh. 2006. Hambatan dan Tantangan dalam Mewujudkan Good Governance melalui Penerapan EGovernment di Indonesia. Depok : Departemen Ilmu Administrasi FISIP UI.

Maryam, Neneng Siti. 2016. Mewujudkan Good Governance Melalui Pelayanan Publik. Bandung : Politeknik Kridatama Bandung.

Sadjijono. 2007. Fungsi Kepolisian dalam Pelaksanaan Good Governance, LAKSBANG.

Sumarto, Hetifah Sj. 2004. Inovasi Partisipasi dan Good Governance. Jakarta : Yayasan Obor Indonesia.

Widodo, Joko. 2001. Etika Birokrasi dalam Pelayanan Publik. Malang: CV Citra.

Kominfo. $2018 . \quad$ Online at http://jatimprov.go.id/read/beritapengumuman/gubernur-lppd-wujudkangood-governance

BPS. $2021 . \quad$ Online at https://www.bps.go.id/KegiatanLain/vie w/id/93

MENPANRB, Humas. 2021. Online at https://www.menpan.go.id/site/berita- terkini/kementerian-panrb-umumkantop-inovasi-pelayanan-publik-terpujitahun-2021

Undang-Undang Dasar Negara Republik Indonesia 1945.

Undang-Undang Republik Indonesia Nomor: 28 Tahun 1999 tentang Penyelenggaraan Negara yang Bersih dan Bebas dari Korupsi, Kolusi, dan Nepotisme.

Undang-Undang Nomor 25 Tahun 2009 tentang Pelayanan Publik.

Peraturan Pemerintah Nomor 101 Tahun 2000 tentang Pendidikan, Pelatihan Jabatan Pegawai Negeri Sipil. 